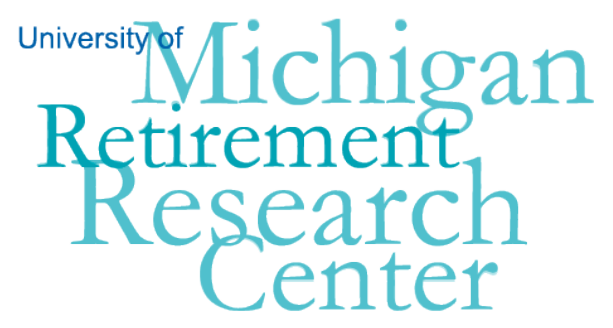

Working Paper WP 2012-276

\title{
Diminishing Margins: Housing Market Declines and Family Financial Responses
}

\author{
Frank P. Stafford, Erik Hurst and Bing Chen
}

\begin{tabular}{|l|l|}
\hline $\mathrm{M}$ & $\mathrm{R}$ \\
\hline $\mathrm{R}$ & $\mathrm{C}$ \\
\hline
\end{tabular}

Project \#: UM11-Q2A 



\title{
Diminishing Margins: Housing Market Declines and Family Financial Responses
}

\author{
Frank P. Stafford \\ University of Michigan \\ Erik Hurst \\ University of Chicago \\ Bing Chen \\ University of Michigan
}

December 2012

\author{
Michigan Retirement Research Center \\ University of Michigan \\ P.O. Box 1248 \\ Ann Arbor, MI 48104 \\ www.mrrc.isr.umich.edu
}

(734) 615-0422

\section{Acknowledgements}

This work was supported by a grant from the Social Security Administration through the Michigan Retirement Research Center (Grant \# 5 RRC08098401-03-00). The study used the Panel Study of Income Dynamics, public use dataset, produced and distributed by the Institute for Social Research, Survey Research Center, University of Michigan, Ann Arbor, MI (2009). The findings and conclusions expressed are solely those of the author and do not represent the views of the Social Security Administration, any agency of the Federal government, or the Michigan Retirement Research Center.

\section{Regents of the University of Michigan}

Mark J. Bernstein, Ann Arbor; Julia Donovan Darlow, Ann Arbor; Laurence B. Deitch, Bloomfield Hills; Shauna Ryder Diggs, Grosse Pointe; Denise Ilitch, Bingham Farms; Andrea Fischer Newman, Ann Arbor; Andrew C. Richner, Grosse Pointe Park ; Katherine E. White, Ann Arbor; Mary Sue Coleman, ex officio 


\title{
Diminishing Margins: Housing Market Declines and Family Financial Responses
}

\begin{abstract}
We utilize data from the Panel Study of Income Dynamics (PSID) to study borrowing decisions and other factors related to the run-up in housing prices in 1999-2007, their precipitous decline in 2007-2009, and how they contributed to mortgage distress and foreclosures as of 2009-2011. Difficulties were concentrated in selected real estate markets where the Case Shiller home index declined more than 35\% from 2007 to 2009. Often expecting further price appreciation or responding to a positive family labor market and income circumstance, homeowners, supported by their lenders, allocated too much of their family income to support house payments and put themselves in a risky position. The year of taking the original mortgage, the rate of decrease in the Case-Shiller home price index, household wealth, and labor market and disability status are substantial predictors of mortgage payment distress and foreclosure.
\end{abstract}




\section{Introduction and Literature}

In this paper, we study the factors related to family level mortgage distress and foreclosure in the U.S. economy, 2007-2011.

Rapid appreciation in home prices has been observed in many advanced economies. In Japan the housing markets for condominiums experienced a sharp rise in prices, 1987-1991, with Tokyo prices leading the way up quickly followed by Osaka prices. Then Tokyo prices led the way, precipitously downward, followed closely by those in Osaka, 1992-1995. The path of the rising prices and then sharply declining prices in Osaka and Tokyo, 1987-1995, has essentially the same shape as the Case-Shiller average of 10 major urban markets in the U.S., 1999-2009. A housing price boom occurred in Scandinavia: in Sweden, housing prices tripled after the mid 1990s, with similar patterns observed in other Northern European countries. In Sweden, a boom developed during 1985-1990. Subsequently, a bust occurred, 1990-1993, with a severe impact on the wider Swedish economy (Jaffé, 1994). ${ }^{1}$

Various factors explaining the presence of a housing bubble include the difficulty of holding a short position in a heterogeneous commodity. Another strand in the literature is that of unfounded optimism in the value of a particular class of investment, including railroads or real estate. This was the premise behind the concepts set out by Irving Fisher (1933) in his effort to understand the Great Depression, and has a modern form in the notion of Keynes' 'animal spirits' or expectation contagion (Akerloff and Shiller, 2009) $)^{2}$

In Fisher's assessment:

\footnotetext{
${ }^{1}$ There was a shift to more favorable tax deductions of mortgage interest, and a dramatic increase in the financing and construction of multi-unit housing ensued. The cycle in commercial real estate was even more acute.

2 Work in neuroscience establishes the presence of a mirror neuron center in the brain which gives rise to human propensities to behave in a pattern 'mirroring' that of others (Iacoboni, 2009).
} 
"The public psychology of going into debt for gain passes through several more or less distinct phases: (a) the lure of big prospective dividends or gains in income in the remote future; (b) the hope of selling at a profit, and realizing a capital gain in the immediate future; (c) the vogue of reckless promotions, taking advantage of the habituation of the public to great expectations; (d) the development of downright fraud, imposing on a public which had grown credulous and gullible."

In particular, the resulting downturn in housing prices and associated delinquencies on mortgages are generally considered to be the major cause of the crisis in credit markets that subsequently spilled into the other sectors of the U.S. economy in the form of a Fisherian debtdeflation. In our study, the most substantial predictor of mortgage distress and foreclosure is the family's allocation of a high share of family income going to housing payments for interest, taxes, and utilities. Higher values of housing payments to family income -- HPI were more common in markets with strong appreciation during the housing boom.

Owner-occupied housing is the major asset in many households' portfolios and across a wide span of the life cycle (Hurst, Luoh, and Stafford, 1998; Wolff, 2010). Housing wealth is an important determinant of consumption and saving behavior of households and is often correlated with savings and better overall financial management. For example, Bostic, Gabriel, and Painter (2009) find that housing wealth has substantial effects on household consumption and the U. S. economy. Dvornak and Kohler (2003), analyzing the data of a panel of Australian states, show that a one dollar permanent increase in housing wealth can cause a three cent increase in long-run annual consumption. As shown by Jaffe (2004), disruptions in the housing market can have widespread and long lasting effects via the connection to other spending and economic activity.

Housing services are the consumption dimension, but on the financial side, recent research (Hurst and Stafford, 2004; Cooper, 2009) supports home ownership as playing a central collateral or liquidity role (Bernanke and Gertler, 1989) - in contrast to the wealth effects found for non-pension holdings of stocks (Juster, Lupton, Smith and Stafford, 2006) and the 'wealth' interpretation offered 
by Bostic, Gabriel and Painter. In the Hurst-Stafford framework there are two motivations for exercising the option to refinance a mortgage. There is a traditional 'financial option' allowing the homeowner to realize a net worth gain and possibly an asset reallocation when an existing mortgage can be refinanced at a lower interest rate. A second motivation for exercising the refinancing option is to tap into equity and 'borrow up' to support consumption.

Exercising this 'consumption option' can lead to refinancing to both a higher loan balance and a higher rate of interest. This perspective has been given added support in the analysis of aggregate data (Greenspan and Kennedy, 2008). A substantial share of equity withdrawals was found to support personal consumption expenditures. Since the different balance sheet components are fungible, this consumption allocation is consistent with equity withdrawal as a supplement to cash flow to spend beyond current cash flow from income sources.

Connected to the 'consumption option' is a third motivation to refinance: borrowing to cover cash flow requirements from home ownership that are induced by interest, tax and utility costs. This refinancing can otherwise be thought of as a "speculation-based liquidity option'. That is, refinancing for a position in housing which embodies a wider set of and higher level of costs. These are costs beyond those related to normal predicted consumption, based on income and family composition. Rather the funds support speculative financing, based on expected appreciation. This appears to have played a major role in the housing market turbulence, 2001-2009. Tapping into perceived equity gains from rising home prices can clearly be risky as changes in the family balance sheet are mixing with expense flows. In short, during the boom, families and their lenders more often took on a jointly speculative position, leading to increased cash flow demands to cover 
housing costs - and reducing liquidity other than from future borrowing on equity gains. In effect, the borrowing collateral was often based on expected future appreciation. ${ }^{3}$

The decisions to invest in housing and hold a substantial mortgage are usually associated with younger households (Flavin and Yamashita, 2002), as part of a life-cycle approach to consumption and asset management (Campbell and Viciera, 2002; Deaton, 2001). But the housing boom of 1999-2005 induced many of those, even 60 years or older, to depart from the prior norm and to hold more housing and have greater mortgage debt than earlier cohorts. In 1986, 20.4 percent of owners age 65-79 held a mortgage on their home. By 2005, this had increased to 35.8 percent. A study by Apgar and Di (2006) reports that mortgage debt owed by older households nearly quadrupled between 1989 and 2001. In 2001, after accounting for inflation, the typical household headed by someone 65 or older had $\$ 44,000$ in mortgage debt, compared with $\$ 12,000$ in 1989 (Apgar and Di, 2006).

Even at the lower mortgage rates, by 2007 mortgage debt payments as well as other expenses for insurance and taxes had become a rising share of family income compared to earlier periods. This was most pronounced in specific urban markets. With rising home expenses and a greater cost of home debt servicing, even elderly homeowners, many of whom live on fixed or limited incomes, found themselves in a financially constrained, or even distressed, liquidity situation should there be a reversal in home prices. As can be seen in Table 1, the 1999-2005 period was characterized by both a higher rate of home ownership and greater persistence in ownership than 1989-1995. When housing prices are on the rise, new demand can maintain the upward trend. Yet in many markets, most families that could afford the new housing and the related costs had already become owners, leaving

\footnotetext{
${ }^{3}$ In part, higher marginal debt service costs were offset by interest deductibility on home mortgages, which should have induced families to hold a larger share of debt in the form of mortgages, even prior to 2005 bankruptcy reforms.
} 
a smaller pool of new potential entrants to further boost demand, at which point the price rise began to stall out.

Before the 2005 U. S. bankruptcy reform, households with financial distress could transfer more money to pay their mortgage and could then file for bankruptcy to discharge other debts. After the bankruptcy reform, the cost for filing for bankruptcy increased and there were greater limitations on what could be discharged. Thus, households with financial problems had more incentive to foreclose on their mortgages. For this reason Bernstein (2008) has argued that the 2005 reform of U.S. bankruptcy law resulted in, or at least precipitated, the increase of mortgage defaults. Morgan, Iverson and Botsch (2011), using 1/1998-3/2007 state-level aggregate data, show that subprime foreclosures increased more in states where home equity exemptions are high after 2005 bankruptcy reform. Li, White, and Zhu (2011), using large samples of individual level mortgage data also show that the 2005 reform of U.S. bankruptcy law led to an increase of mortgage defaults. Possibly these early foreclosure sales were enough to precipitate the downward price path for housing in numerous markets.

Crouhy, Jarrow, and Turnbull (2008) argue that banks implemented some risky actions before the real estate bubble burst. Demyanyk and Hemert (2009) show that the quality of loans decreased greatly during the dramatic expansion of the subprime (securitized) mortgage market. On the other side of the mortgage market, households also may take risky positions before the burst of the real estate bubble. Campbell (2003) shows that people with low risk aversion would be more likely to take Adjustable Rate Mortgages (ARM). Some other papers (Mayer, Pence, and Sherlund, 2009; Coulibaly and Li, 2009; and Immerqluck, 2009) also discuss the risky position of lenders and borrowers in the mortgage market.

Here we explore some of the themes outlined above by using the data in the longstanding, nationally representative Panel Study of Income Dynamics (PSID) of approximately 8,600 families 
and 24,000 individuals living within these families. For our analysis we use a balanced panel of married families, who had home mortgages, 2007-2009. PSID data includes housing and wealth holdings and basic geospatial measures. New measures include data on foreclosure and mortgage distress added in 2009 - 2011 and on fixed/adjustable mortgage rates added in 2007 and 2009. Our results show that specific ex ante positions in 2007 do matter for future mortgage payment problems in 2009 and subsequent foreclosure. Race and education level of head, number of people in household, year of taking the original mortgage, the rate of decrease in the markets included in the Case-Shiller home price index, the ratio of housing payments to family income, employment status in 2009, and wealth level without equity are all highly related to 2009 mortgage distress and subsequent foreclosure.

\section{Net Worth, Emerging Patterns of Assets and Home Mortgage}

We review selected basic patterns of household net worth for those headed by a person age 65 and older and of those at midlife, age 40-49, along with age profiles of participation on the home mortgage market over time. In Table 2 it can be seen that over the period, 2001-2007, those age 65 and older experienced a substantial rise in the constant dollar value of their net worth. The median value of net worth rose modestly but was generally quite stable. The rise in net worth of families age 65-79 has been documented elsewhere. ${ }^{4}$ The younger or midlife group age 40-49, which could be thought of as including the 'younger generation,' and likely to seek help from the elders in times of need also had substantially more net worth as of 2007 compared to 2001 . On the other hand,

\footnotetext{
4 The average net worth of those age 65-79 more than doubled in constant dollars from 1984-2001 and the income relative to Census Needs also rose strongly for this group, especially for those in better health. See Grafova, McGonagle and Stafford, 2005 "Functioning and Well-Being in the Third Age, 1986-2001," in The Crown of Life: Dynamics of the Early Post-Retirement Years (Jacquelyn B. James and Paul Wink, eds.), 2006.
} 
financial net worth, cash or that which can be readily converted into cash, shows no growth at the mean or median, 2001-2007, for those 65 or older, and, in fact, declined modestly.

For those age 40-49 the mean financial wealth shows no clear improvement, 2001-2007, and the median financial wealth shows a low and declining real value, 2001-2007. Of some concern is that moving toward 2007 the liquid financial net worth was declining, especially relative to overall net worth, and is persistently low and declining, especially at the median. The median for this age group was persistently under $\$ 10,000$ (\$2007). The debt growth was fully observed at that time (Dynan and Kohn, 2007). As financial vicissitudes arise, these midlife course families had limited net liquid reserves with which to deal with negative financial shocks ${ }^{5}$. The rise of net worth, substantially driven by home price appreciation, was characterized by a constant or slightly declining financial net worth.

Age profiles of home mortgage holding among homeowners, based on the full weighted sample of the PSID, 1979 to 2007, are in Figure 1. The top line is for those headed by a family age 25-34, and just below are the families age 35-49. Both show the persistently high rates for those families headed by a 25-49 year old. The middle line is for families headed by a 50-64 year old. About half of these families held a mortgage from 1979 to the early 1990s and then the share of these homeowners with a mortgage rose to about 70 percent after 1999 . The lowest line is for families headed by an individual age 65 or older. Over the period we can see a rise for older families from under $20 \%$ with a mortgage to about $30 \%$ by 2007 . Another reference point is the dip in

\footnotetext{
${ }^{5}$ The 2007 value of non-collateralized debt, especially burdensome in a cash flow crisis, shows that of the families who hold any had a total balance averaging \$21,500. See 'Trends in Household Wealth Dynamics, 2005-2007.' Technical paper Working Paper Series, September, 2009. http://psidonline.isr.umich.edu/Publications/Papers/tsp/200903_Trends_in_Household_Wealth.pdf
} 
mortgage holding in the early 1990s, a period with high mortgage rates, followed by a rebound in mortgage holding as rates came down in the mid and later 1990s.

One related measure of housing and mortgage contract position is a micro level version of the Debt Service Ratio (DSR) maintained by the Federal Reserve Board. This aggregate index shows an upward movement in cash flow burden of mortgages up through $2007 .{ }^{6}$ At the micro level, the PSID data show both a rising and dispersed ratio of mortgage debt to family income (DSR). Holding a high mortgage-based DSR is one measure of a family's housing risk. The expectation of additional future increases in home prices and continued employment can be the motivation for enduring a higher current cash flow burden. Expanding this to include all other housing related payments relative to family income, housing payments to income (HPI) provides another measure of housing service cost burden.

Included in HPI are payments for interest on the first and second mortgage, and with rising house prices come rising real estate taxes, and along with utilities, the cash flow going into owner occupied housing was on the rise, 1990-2007. Retrospectively, we may want to conclude that these were evident patterns of 'excess' in the housing and mortgage market and related to the various mortgage quality measures reported from industry data. At the time of the upswing, observers could refer to stable and falling ex post loan-to-value ratios, but these were often driven by home price appreciation that did not persist, mostly in the markets with rapidly rising home prices. Edward Gramlich (2007) noted that one aspect of the 1995-2005 U.S. housing pattern was higher ownership rates with a wider demographic distribution. This can be seen in Table 1. Some families persisted as renters and others, in addition to being new or continuing owners took on very risky positions with

\footnotetext{
${ }^{6}$ As noted by Alan Greenspan (2004), even with lower mortgage rates, the added mortgage value outstanding can lead to a higher debt service ratio for home mortgages.

http://www.federalreserve.gov/boarddocs/speeches/2004/20041019/default.htm
} 
non-traditional mortgages (NTM's). Specifically, they (and their lenders) often chose variable rate mortgages or a balloon repayment and a short horizon, or a reborn use of second mortgages. The PSID panel data show these and other aspects of housing and mortgage decisions.

\section{The Spatial and Household Distribution of NTM's and the Cash Flow Position}

What measures are clear indicators of a risky housing position prior to the declines in the market? The existing PSID data show that 2005 loan to value ratios, as a measure of the homeowner's leverage position, are problematic. Even mortgages with a high LTV, well above a 'safe' level of $80 \%$ or more in home equity at the point of mortgage settlement, ${ }^{7}$ were often driven downward by rapid home price increases, producing an ex post 'safe' mortgage. By 2007, the normal strong relationship between permanent income and the house value (not shown here) became much weaker. Going forward to 2009 , some of the ex ante 'safe' mortgages sunk 'under water' with rapidly declining home values, 2007-2009. By 2009, most of the acute declines had ended, and the net equity position ex post can be observed as an outcome. Which families are these? Who are those experiencing this 'collateral damage’? How strongly does the 2007 housing payments to income (HPI) ratio, likely a better ex ante risk measure, relate to such an outcome?

The share of the 2007 mortgages which were non-traditional mortgages (NTM's) included variable rate mortgages (ARM's). The ARM share was rising from 1997 to 2007, as shown in Figure 2. The rise is even stronger, given the reports were from a March to December field period in 2007, and that given the 2001-2004 and 1997 - 2001 periods are for 4 year intervals. Also, the share of ARMS is highly concentrated in California, Florida and Arizona, states in which urban centers had strong run-ups in the Case-Shiller repeat home sales index - and had the same cities leading the

\footnotetext{
${ }^{7}$ Data in the Financial Crisis Inquiry Report, The Financial Crisis Inquiry Commission, U.S. Government Printing Office, January, 2011 indicate that high LTV's at the point of loan origination were a rising share of new mortgages.
} 
parade of declining prices from mid-2007 to mid 2009 (Phoenix, Miami, Tampa Bay, San Diego, Los Angeles and San Francisco). Texas shows a far lower rate of refinancing, and Dallas shows an attenuated price run-up and a far lower subsequent decline in home prices, 2007-2009. ${ }^{8}$

Homeowners in the age range 55-64 had the highest percentage of ARMs. Income was negatively correlated with ARMs, indicating that the higher the income, the less likely a homeowner was to have obtained an ARM. A higher incidence of ARM refinancing among those with less education was also a pattern. ${ }^{9}$

Homeowners residing in California and Arizona were most likely to obtain a second mortgage for their homes. The trend in second mortgages, a re-born mortgage type, parallels that of ARMs with regard to year of origin. The majority of homeowners obtained their second mortgage either before 1997 or between the years 2005 and 2007. In contrast to ARMs, there is a negative correlation between age and second mortgage. While only $1.2 \%$ of the 65 and older homeowners obtained a second mortgage, $8.1 \%$ of homeowners younger than 35 years old had a second mortgage.

There was a general rise in the share of income going to support homeowner expenses for all age groups. While stronger for younger families, there was also a rise for those age 50 and older. In addition, many homeowners had refinanced in the near term, especially is selected states. Given the position of families with respect to housing in 2007, how important are 2007 HPI (housing payments relative to family income) and other 2007 mortgage measures in predicting the various

${ }^{8}$ An explanation for the attenuated pattern in Dallas is that the long run supply of new homes is more elastic, so anticipation of strong permanent gains was limited.

${ }^{9}$ As of February 2011 it was reported from industry data that Option ARM foreclosures stood at a rate higher than Subprime foreclosures ever had reached (Source: World Property Channel www.worldpropertychannel.com/us-markets $7 / 6 / 2011)$ 
outcomes in 2009 - falling behind in payments, mortgage modification, expecting to fall behind in the next 12 months, and foreclosure?

\section{Distress Indices and Analysis}

Here we show how these ex ante risk positions played out as the housing market and the wider economy deteriorated, 2007-2009. For this we have used the PSID family files in 2009 which measure a set of mortgage distress indicators, or adverse outcomes. These range from no observed problems to modest reported risk of payment problems in the next 12 months, to having fallen behind substantially in making payments, the need to modify the mortgage because of payment problems (not normal refinancing), negative home equity, and then actual foreclosure. Specifically, we have explored the following outcomes:

1 Falling behind. This is based on the variable (A27F1) $1=$ yes, $5=$ no from the questionnaire. There are no values of ' 8 or 9'. Here the measure $=1$ if the answer is 1 , and the measure $=0$ if the answer is 5 and all others.

$2 \quad$ Next 12 Months (A27F6) fall behind? 1=very likely, $3=$ somewhat likely, 5= not at all likely. We define the value of this measure is 1 for the "very likely" case, 0.5 for the "somewhat likely" case, and 0 for the "not at all likely" case.

3 Mortgage Modification (A27F5) $(1=y e s ; 5=$ no) Here the measure $=1$ if the answer is 1 , and the measure $=0$ if the answer is 5 and all others.

4 Under water 1. Here we have the cases where a dollar value of the home was reported. The unfolding bracket cases are likely to create classification problems. The ratio is (for valid dollar value of home value on the market - excluding bracket range values $s$ and 'don't know') the sum of (A24MOR1 + A24 MOR2) divided by A20 = sum of mortgage balances / house value (value of house if sold today). This was converted into 1-0 under water dummy variable $=$ sum of mortgages $/ \mathrm{hv}>1.00$ or not. 
5 Under water 2. This measure is based on the difference between the wealth with home equity (WEALTH2) and the wealth without home equity (WEALTH1). We define under water 2 equal to 1 if WEALTH2-WEALTH1<0 and equal to 0 if WEALTH2-WEALTH1 $>0 .{ }^{10}$

6 Foreclosure, 2009-2011. The case count here is first restricted to those who report being in foreclosure as of the 2009 interview (A27F3) plus those who report a foreclosure in the 2001-2009 time windows (A37F1). To provide a measure of recent foreclosures, this overall group gets reduced by 2 factors. First are the foreclosures, 2001-2008 (from A37F2), which occurred either before information was collected on whether the mortgage rate was variable and other aspects of the mortgage, or before the onset of household financial pressures related to the financial crisis, which we assume began mostly as of calendar year 2009. ${ }^{11}$ Another group is excluded because the property foreclosed upon was not their primary residence (A37F5) (1=own home, 2= investment property, $3=$ vacation home/condo, 7 = other specify). Foreclosures on the primary residence as of 20092011 were observed these restrictions.

Each of the above six measures only partly captures mortgage distress. We constructed a set of mortgage distress indices based on measures (1-5) to capture the overall mortgage distress of households, including a distress index by principal component analysis partly as a robustness check. Since foreclosure has relatively few cases ( 74 recently completed foreclosure cases, or 4\% out of 1827 panel observations), and is quite distinct from pre-foreclosure distress, a separate estimation was implemented.

\section{Outcomes and Discussion}

The mortgage distress index (Index 1) for Table 3 Column 1 was constructed by summing up measure 1 through measure 5. It has 10 possible values and ranges from 0 to 4 . We estimated the

\footnotetext{
${ }^{10}$ Measure 4 is limited to those providing specific dollar answers to the questions on house value and outstanding mortgage balance(s). Measure 5 includes every mortgage holder even if they gave bracket answers and had missing information. For example they knew the monthly mortgage payment and interest rate and years to pay - but not the balance remaining and that was estimated from those elements given. Measures 4 and 5 have a correlation of .80 and are used as multiple indicators of being under water - each receiving a weight of .5.

11 There is always a baseline level of foreclosures and we want to separate those out from those induced by the contraction.
} 
OLS regression of this and three other variants of the mortgage distress index on baseline regressors and those specifically for our housing, financial and labor market variables. The models include several family and demographic variables known to predict mortgage problems (Webb, Friedberg and Dushi, 2010): age, race, marital status and education level of head, and the number of people in household at a given income level.

Of direct interest are the financial variables: the 2009 interview date (with after August 2009 indicating more time exposure to financial risk), whether the mortgage was the original mortgage, the year of taking the original mortgage, the $(7 / 2007$ - 7/2009) rate of decrease in the Case Shiller home price index, ${ }^{12}$ the ratio of housing payments to family income (HPI) in 2007. The estimated coefficient of "year of original mortgage" is significantly positive at the $1 \%$ level. Households with more recent original mortgages were more likely to have mortgage payment troubles in 2009 . The U.S. real estate bubble achieved its peak in early 2006 and then the price of real estate started to decrease from later in 2006 until 2011. The closer to 2007 is the time of taking the original mortgage, the more likely to reflect risky mortgage positions for both households and lenders because, as we now know, the anticipated future increases were not to be.

The second group of variables includes the income and balance sheet measures. The income of the husband and wife has been collected in summary form for two calendar years prior to the year of the interview. This provides an approximate measure of family income for 2007. Higher income of the head and wife in calendar year 2008 is strongly predictive of less mortgage distress. On the other hand, income as of 2007 has a modest positive relationship to mortgage distress as of 2009 . One conjecture is that having a good income flow in 2007 was often conducive to the families and their

\footnotetext{
12 The models also included region and urbanicity, which evidenced limited correlation [to other variables], except for the very largest cites, for Index 1 and Index 2.
} 
OLS regression of this and three other variants of the mortgage distress index on baseline regressors and those specifically for our housing, financial and labor market variables. The models include several family and demographic variables known to predict mortgage problems (Webb, Friedberg and Dushi, 2010): age, race, marital status and education level of head, and the number of people in household at a given income level.

Of direct interest are the financial variables: the 2009 interview date (with after August 2009 indicating more time exposure to financial risk), whether the mortgage was the original mortgage, the year of taking the original mortgage, the $(7 / 2007$ - 7/2009) rate of decrease in the Case Shiller home price index, ${ }^{12}$ the ratio of housing payments to family income (HPI) in 2007. The estimated coefficient of "year of original mortgage" is significantly positive at the $1 \%$ level. Households with more recent original mortgages were more likely to have mortgage payment troubles in 2009 . The U.S. real estate bubble achieved its peak in early 2006 and then the price of real estate started to decrease from later in 2006 until 2011. The closer to 2007 is the time of taking the original mortgage, the more likely to reflect risky mortgage positions for both households and lenders because, as we now know, the anticipated future increases were not to be.

The second group of variables includes the income and balance sheet measures. The income of the husband and wife has been collected in summary form for two calendar years prior to the year of the interview. This provides an approximate measure of family income for 2007. Higher income of the head and wife in calendar year 2008 is strongly predictive of less mortgage distress. On the other hand, income as of 2007 has a modest positive relationship to mortgage distress as of 2009 . One conjecture is that having a good income flow in 2007 was often conducive to the families and their

\footnotetext{
12 The models also included region and urbanicity, which evidenced limited correlation [to other variables], except for the very largest cites, for Index 1 and Index 2.
} 
city is presumably independent of the financial situation of the individual household and its ability to pay the mortgage as reflected in the family-specific financial and income measures.

Unemployment, income level, balance sheet measures, the household being in a city with $35 \%$ or more home price decline predict likely payment troubles. Rapidly decreasing house prices in a city can be a signal of poor current and anticipated labor market and income levels. This poor prospect gives households more anticipated difficulties and greater incentives to consider foreclosure on their own mortgages, a type of financial contagion. Further, a large price decrease may cause anxiety for the household, and this by itself can shape expectations about ability to pay in the next 12 months. ${ }^{13}$ The other significant predictor of mortgage payment trouble is the HPI in 2007.

The estimated coefficient (.235) is significantly positive at the $1 \%$ level. Consider variation of a standard deviation (.120) above and below the mean of .189. This would induce an increase in the distress index of $.056(.240$ times .536). A high value of HPI is an indicator of a risky cash flow position, and is an alternative to the traditional index of a 'safe mortgage', the loan-to-value ratio (LTV) of .80 or less. While LTV can be shaped by rapid house price appreciation, if the value of HPI is high ${ }^{14}$, the ability of the household to pay the mortgage can be compromised with a deterioration of employment status or other negative financial shocks, including a decline in the market value of the home.

To check the robustness of our results, we constructed two additional indices (Index 3 and Index 4) and estimated a regression structure similar to Index 1 and Index 2. For Index 3, we first estimated the OLS regression of each mortgage distress measure on all the other mortgage distress

\footnotetext{
${ }^{13}$ The correlation of the mortgage distress measures and reported life satisfaction was significantly negative. 14 "People [in Bakersfield, California] didn't seem to have enough income to pay for what they had bought." Financial Crisis Inquiry Report, p. 43.
} 
measures and kept the fitted values of each regression. Then, applying a principal component analysis for the fitted values, we defined the first dimension of the PCA as Index 3. Index 4, built up in the same way as Index 3, except that we did not include the measure 4 and measure 5 to rule out the effect of house value declines on the index. The regression results of Index 3 and Index 4 are shown as III and IV. Most conclusions from Index 1 and 2 hold for Index 3 and Index 4. Overall, the results about the number of people in the household, year of taking the original mortgage, the rate of decrease of Case Shiller index $>=35 \%$, HPI, the head 'keeping house' as of 2009, income of wife in 2008, and net worth excluding home equity are relatively stable across different models.

\section{Analysis of Foreclosure 2009-2011}

The process of foreclosure unfolds over time. By 2009 there was substantial mortgage distress while the number of actual foreclosures observed by the date of the interview was rather small and may have been part of the normal incidence of foreclosure rather than in the context of the financial crisis. By adding in the foreclosures reported looking back from the date of interview in 2011 we were able to obtain a better measure of the eventual foreclosure outcome. For 2009-2011 (date of interview) a total of 74 foreclosures (of 1,821 panel observations) were reported as having at least been started. Estimating a model with Index 5, Foreclosure, 2009-2011, with the same covariates as in Index 1, we have the results for the main variables of interest in Table 4.

The date of interview as of 2009 becomes less important, given the wider time window to observe the adverse outcome. For the central mortgage, Case-Shiller and housing payments to income (HPI), the predictive power for a foreclosure is comparable to the results for Indices 1-4, and the recent (as of 2007) mortgages are those most likely to end up in foreclosure. The relationship with income in the different years is of interest. Greater income of the head and wife as of 2008 predicts a lower foreclosure probability. In contrast, greater income by the head and wife in 2007 before the recession predicts a greater risk of foreclosure, 2009-2011. It seems as if ample 
current income as of 2007 led the families and their banks to commit to more housing, while more income as of 2008 when the recession was coming in provided the cash flow to reduce the subsequent foreclosure risk.

Li, White, and Zhu (2011) provide evidence that the 2005 reform of U.S. bankruptcy law was a factor in the increase of mortgage defaults. In the foreclosure model, wealth as of 2007 plays a more important role than for Indices 1-4. That is, foreclosure is more strongly predicted by a wider range of 2007 balance sheet items and not by a narrow liquidity measure, as were the distress indices. Higher wealth can be interpreted as reducing incentives to engage in recomposing assets to gain from a foreclosure. Alternatively, the role of medium levels of baseline net worth may simply help preclude the need for both bankruptcy and foreclosure.

Adverse labor market measures for the husband as of 2007 show a positive relation to foreclosure as of 2008-2011. For the wife, however, a weak labor market connection as of 2007 is somewhat parallel to the income measures across the years 2007 and 2008. That is, a wife being unemployed, retired, disabled or keeping house (out of the labor force) as of 2007 has a negative relation to the later foreclosure outcome. This suggests that a weak labor market connection of the wife as of 2007 led families and lenders to be more cautious about mortgage commitments. Then, as of 2008-09, most negative labor market indicators for both the husband and wife are positive predictors of foreclosure. The exception is the modest positive relation between foreclosure and weeks worked of the head as of 2008, possibly a labor supply response to foreclosure risk. ${ }^{15}$

\footnotetext{
15 The relation between foreclosure and the demographic variables are similar to those for Indices 1-4. Net of the reported covariates region, city size, age of head had little relationship to foreclosure.
} 


\section{Conclusion}

A main reason for mortgage payment troubles of households in 2009 can be found in the prior mortgage decisions. Often expecting further price appreciation or responding to a positive family labor market and income circumstance, homeowners allocated too much of their family income to support house payments and put themselves in a risky position. From our perspective, the strong connection of the high cash flow service burden on housing, from debt service and other housing costs, can inform future assessments of rising risk in residential housing. Committing a high share of family income to housing, or substantial mortgage borrowing relative to current family income is an indication that the family expects a price rise to reward their current payment burden or that they simply have housing which is likely beyond their means. Continued appreciation was often not borne out in 2007-2009, nor was the income needed to support the housing commitment, and both of these may re-occur in the future.

In the Dodd-Frank bill the "ratios of total monthly debt to monthly income or alternate measures of ability" to pay should be considered when determining whether a mortgage is a "qualified mortgage" or not. ${ }^{16}$ At a minimum, to develop market measures to assess the quality of existing mortgages, a measure of cash flow commitments to housing could be monitored along with the traditional index of loan to value (LTV). Given the heterogeneity across housing markets, the HPI ratio could be measured for individual urban housing markets such as those in the Case-Shiller index, using micro data such as the PSID, the Survey of Consumer Expenditures or the Survey of Income and Program Participation. An even more readily available measure is the price of homes relative to income. This ratio doubled during the recent price cycle in United Kingdom housing.

\footnotetext{
1615 USC 1639c(b)
} 
Such a measure could serve as an early warning indicator and lead to a disaggregated geospatial assessment, looking at both the income of families and the cash flow for debt service and other costs to support their housing position. 


\section{References}

Akerlof, George A. and Robert J. Shiller, Animal Spirits: How Psychology Drives the Economy and Why it Matters for Global Capitalism, Princeton University Press, 2009.

Apgar W. C. and Zhu Xiao Di (2006),’Housing Wealth and Retirement Savings: Enhancing Financial Security for Older Americans," in the Oxford Handbook of Pensions and

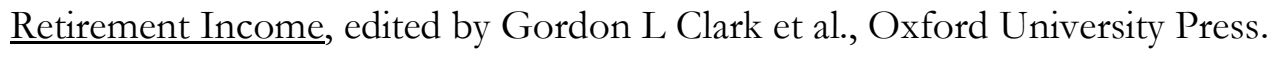

Bernanke, Ben and Mark Gertler, “Agency Costs, Net Worth, and Business Fluctuations,” American Economic Review, March, 1989, p.14-31.

Bernstein, David P., "Bankruptcy Reform and Foreclosures”, SSRN working paper, July 2008.

Bostic, Raphael, Stuart Gabriel, and Gary Painter, "Housing Wealth, Financial Wealth, and Consumption: New Evidence from Micro Data," Regional Science and Urban Economics, 2009 (39), p. 79-89.

Campbell, John Y. and João F. Cocco, "Household Risk Management and Optimal Mortgage Choice," The Quarterly Journal of Economics, November, 2003, p. 1449-1494.

Campbell, John Y. and Luis Viceira, $\underline{\text { Strategic Asset Allocation: Portfolio Choice for Long-Term }}$ Investments, Clarendon Press, Oxford, 2002.

Cooper, Daniel, Essays on Housing Wealth and Consumer Behavior, Ph.D. dissertation, University of Michigan, Department of Economics, 2009.

Coulibaly, Brahima and Geng Li, "Choice of Mortgage Contracts: Evidence from the Survey of Consumer Finances,” Real Estate Economics, Winter 2009, p.659-673.

Crouhy, Michel G., Robert A. Jarrow, and Stuart M. Turnbull, “The Subprime Credit Crisis of 07," The Journal of Derivatives, Fall 2008, p. 81-110.

Deaton, Angus, Understanding Consumption, Clarendon Press, Oxford, 1991. 
Demyanyk, Yuliya and Otto Van Hemert, "Understanding the Subprime Mortgage Crisis," The

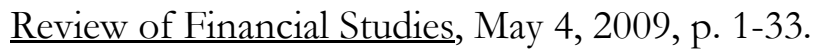

Dvornak, Nikola and Marion Kohler, "Housing Wealth, Stock Market Wealth and Consumption: A Panel Analysis for Australia," Research Discussion Paper, Reserve Bank of Australia, 2003.

Dynan, Karen E. and David L. Kohn, “The Rise in U.S. Household Indebtedness: causes and Consequences,” FEDS Working Paper No. 2067, August, 2007.

Fisher, Irving, “The Debt-Deflation Theory of Great Depressions,” Econometrica, Vol. 1 No. 4, p. $337-357$.

Flavin, Marjorie and Takishi Yamashita, "Owner-Occupied Housing and the Composition of the Portfolio," American Economic Review, March, 2002, p. 345-362.

Gramlich, Edward M., The Subprime Crisis: America's Latest Boom and Bust, Urban Institute, Washington, D.C., 2007.

Greenspan, Alan and James Kennedy, "Sources and Uses of Equity Extracted from Homes," Oxford Review of Economic Policy, Vol. 24, No. 1, 2008, p. 120-144.

Hurst, Erik, Ming Ching Luoh, and Frank P. Stafford, "Wealth Dynamics of American Families, 1984-1994", Brooking Papers on Economic Activity, 1998 (1), p. 267-338. , and Frank P. Stafford, "Home is Where the Equity Is: Mortgage Refinancing and Household Consumption, Journal of Money Credit and Banking, December 2004, p.9851014.

Iacoboni, Marco. Mirroring People: The Science of Empathy and How We Connect with Others. Picador . 2009.

Immerqluck, Daniel, Foreclosed: High-Risk Lending, Deregulation, and the Undermining of America’s Mortgage Market, Cornell University Press, June, 2009. 
Jaffé, Dwight, “The Swedish Real Estate Crisis,” A Report Prepared for the Studieförbundet Näringsliv och Samhälle, Center for Business and Policy Studies, SNS, Stockholm, Sweden, October, 1994

Juster, F. Thomas, Joseph Lupton, James P. Smith and Frank P. Stafford, “The Decline in Household Savings and the Wealth Effect," Review of Economics and Statistics, 2006.

Li, Wenli, White, Michelle J., and Zhu, Ning, “ Did Bankruptcy Reform Cause Mortgage Defaults to Rise?”, NBER working paper 15968, 2011

Mayer, Christopher, Karen Pence, and Shane M. Sherlund, “The Rise in Mortgage Defaults,” Journal of Economic Perspectives, Winter 2009, p. 27-50.

Morgan, Donald P., Benjamin Iverson, and Matthew Botsch, "Did the 2005 Bankruptcy Reform Increase Subprime Foreclosures?” Federal Reserve Bank of New York Economic Policy Review, 2011, forthcoming

Webb, Anthony, Leora Friedberg and Irene Dushi, "What is the Impact of Foreclosures on Retirement Security?” Center for Retirement Research, Boston College, Paper 2101-20, 2010.

Wolff, Edward N., "Recent Trends in Household Wealth in the United States: Rising Debt and the Middle-Class Squeeze-An Update to 2007,” Working Paper No. 589, Levy Economics Institute of Bard College, 2010. 
Table 1. The Rise of Persistent Home Ownership, 1989-2005

\begin{tabular}{|l|l|l|l|}
\hline \multicolumn{4}{|c|}{1989 - 1995 -- All Respondents Ages 30-60 } \\
\hline & Don't Own 1989 & Own 1989 & Total \\
\hline Don't Own 1995 & $25.66 \%$ & $4.74 \%$ & $30.40 \%$ \\
\hline Own 1995 & $10.74 \%$ & $58.86 \%$ & $69.60 \%$ \\
\hline Total & $36.40 \%$ & $63.60 \%$ & $100 \%$ \\
\hline
\end{tabular}

\begin{tabular}{|l|l|l|l|}
\hline \multicolumn{4}{|c|}{1999 - 2005 -- All Respondents Ages 30-60 } \\
\hline & Don't Own 1999 & Own 1999 & Total \\
\hline Don't Own 2005 & $22.39 \%$ & $5.07 \%$ & $27.47 \%$ \\
\hline Own 2005 & $10.81 \%$ & $61.72 \%$ & $72.53 \%$ \\
\hline Total & $33.20 \%$ & $66.80 \%$ & $100 \%$ \\
\hline
\end{tabular}


Table 2. Household Net Worth ${ }^{17}$ (NW) and Financial Net Worth (FNW), 2001-2007 (\$2007)

\begin{tabular}{||c|c|c|c|c||}
\hline AGE & 2001 & 2003 & 2005 & 2007 \\
\hline $65+$ & & & & \\
\hline NW Mean & 463.5 & 486.4 & 488.5 & 575.5 \\
\hline NW Median & 218.5 & 204.3 & 208.1 & 237.1 \\
\hline FNW Mean & 238.8 & 255.0 & 222.8 & 237.7 \\
\hline $\begin{array}{c}\text { FNW } \\
\text { Median }\end{array}$ & 48.7 & 48.4 & 42.5 & 42.0 \\
\hline $40-49$ & 82.3 & 73.8 & 81.7 & 90.0 \\
\hline NW Mean & 267.8 & 257.4 & 306.5 & 367.2 \\
\hline NW Median & 83.5 & 103.5 & 121.7 & 100.1 \\
\hline FNW Mean & 123.5 & 8.2 & 8.0 \\
\hline FNW Medn & 9.7 & 8.0 & & \\
\hline \hline
\end{tabular}

\footnotetext{
${ }_{17}$ These are the same definitions as used in "Wealth Dynamics of American Families, 1984-1994," (Erik Hurst, Ming Ching Luoh and Frank P. Stafford), Brookings Papers on Economic Activity, 1998: 1, p. 276-337. However, as of 1999 the value of IRAs in the PSID was obtained in a separate question sequence.
} 
Table 3. Mortgage Distress Index

\begin{tabular}{lllll}
\hline & Index 1 & Index 2 & Index 3 & Index 4 \\
\hline Interviewed after August 2009 & $(1)$ & $(2)$ & $(3)$ & $(4)$ \\
\hline & $0.1669^{* *}$ & $0.1744 * * *$ & 0.0128 & $0.0551^{* * *}$ \\
& $(0.0749)$ & $(0.0605)$ & $(0.0409)$ & $(0.0175)$
\end{tabular}

\begin{tabular}{l}
\hline MORTGAGE AND FINANCIAL MEASURES \\
Whether original mortgage $(0 / 1)$ \\
Year of original mortgage \\
Case-Shiller index decline $(07-09)>=15 \%$ but \\
$<35 \%$
\end{tabular}

Case-Shiller index decline (07-09) $>=35$

Housing payment ratio (HPI)

$\begin{array}{llll}0.0081 & -0.0194 & 0.0289 * & -0.0055 \\ (0.0322) & (0.0260) & (0.0175) & (0.0075) \\ 0.0183^{* * *} & 0.0127 * * * & 0.0079 * * * & 0.0035^{* * *} \\ (0.0040) & (0.0032) & (0.0022) & (0.0009)\end{array}$

$\begin{array}{llll}0.0142 & 0.0150 & -0.0013 & 0.0053 \\ (0.0686) & (0.0554) & (0.0374) & (0.0161) \\ 0.2348^{* * *} & 0.0869 & 0.1847 * * * & 0.0279 \\ (0.0738) & (0.0596) & (0.0402) & (0.0173) \\ 1.4105^{* * *} & 1.0362^{* * *} & 0.5513^{* * *} & 0.2724 * * * \\ (0.1493) & (0.1205) & (0.0814) & (0.0349)\end{array}$

INCOME AND BALANCE SHEET $(\$ 1,000)$

Income head 2007

Income head 2008

Income wife 2007

Income wife 2008

Number of people in household

Wealth without equity $2007<0$

Value of checking and saving $2007<=2000$

LABOR MARKET STATUS

Laid off head 2007

Unemployed head 2007

Retired head 2007

Disabled head 2007

Keeping house head 2007

No wife 2007

Laid off wife 2007

$\begin{array}{llll}0.5606 & 0.4086 & 0.2489 & 0.1575 \\ (0.4736) & (0.3824) & (0.2582) & (0.1109) \\ -0.8364^{*} & -0.6820^{*} & -0.2911 & -0.2377 * * \\ (0.4662) & (0.3764) & (0.2541) & (0.1091) \\ 1.8557 & 1.1984 & 0.9078 & 0.3506 \\ (1.1545) & (0.9322) & (0.6293) & (0.2702) \\ -2.4862^{* *} & -1.6190^{*} & -1.2021 * * & -0.4888^{* *} \\ (1.0397) & (0.8395) & (0.5667) & (0.2433) \\ 0.0332^{* *} & 0.0386^{* * *} & -0.0013 & 0.0110^{* * *} \\ (0.0136) & (0.0109) & (0.0074) & (0.0032) \\ 0.0970^{*} & 0.0768^{*} & 0.0332 & 0.0211 \\ (0.0570) & (0.0460) & (0.0311) & (0.0133) \\ 0.0841^{* *} & 0.0860^{* * *} & 0.0112 & 0.0317 * * * \\ (0.0393) & (0.0318) & (0.0214) & (0.0092) \\ & & & \\ 0.2404 & 0.2980 & -0.0458 & 0.0872 \\ (0.2688) & (0.2170) & (0.1465) & (0.0629) \\ 0.2407 * * & 0.2142^{* *} & 0.0536 & 0.0440 \\ (0.1154) & (0.0932) & (0.0629) & (0.0270) \\ -0.1464 & -0.1247 & -0.0399 & -0.0419^{*} \\ (0.1072) & (0.0866) & (0.0585) & (0.0251) \\ -0.2133 & -0.1289 & -0.1043 & -0.0196 \\ (0.1719) & (0.1388) & (0.0937) & (0.0402) \\ -0.7037 * * & -0.5323 * * & -0.2470 & -0.1592^{* *} \\ (0.2893) & (0.2336) & (0.1577) & (0.0677) \\ -0.0404 & 0.0743 & -0.1227 * * & 0.0210 \\ (0.0967) & (0.0781) & (0.0527) & (0.0226) \\ 0.2172 & 0.1143 & 0.1251 & 0.0226\end{array}$


Unemployed wife 2007

\begin{tabular}{|c|c|c|c|}
\hline$(0.1748)$ & $(0.1412)$ & $(0.0953)$ & $(0.0409)$ \\
\hline 0.0494 & 0.0324 & 0.0305 & -0.0027 \\
\hline$(0.1638)$ & $(0.1323)$ & $(0.0893)$ & $(0.0383)$ \\
\hline 0.0568 & 0.0360 & 0.0265 & 0.0076 \\
\hline .1221$)$ & $(0.0986)$ & $(0.0665)$ & $\begin{array}{l}(0.0286) \\
-\end{array}$ \\
\hline$-0.3902^{* * *}$ & $-0.2690 * *$ & $-0.1789 * *$ & $0.0906^{* * *}$ \\
\hline$(0.1469)$ & (0.1186) & (0.0801) & $(0.0344)$ \\
\hline-0.0779 & -0.0171 & $-0.0745^{* *}$ & -0.0117 \\
\hline$(0.0638)$ & $(0.0515)$ & $(0.0348)$ & $(0.0149)$ \\
\hline 0.2612 & 0.2229 & 0.0738 & $0.0885^{* *}$ \\
\hline$(0.1902)$ & $(0.1536)$ & $(0.1037)$ & $(0.0445)$ \\
\hline $0.4255^{* * *}$ & $0.3667 * * *$ & $0.1134^{* * *}$ & $0.1208^{* * *}$ \\
\hline$(0.0747)$ & $(0.0603)$ & $(0.0407)$ & $(0.0175)$ \\
\hline $0.4692^{* * *}$ & $0.4497 * * *$ & 0.0706 & $0.1372^{* * *}$ \\
\hline (0.1518) & $(0.1226)$ & $(0.0828)$ & $(0.0355)$ \\
\hline $0.7598^{* * *}$ & $0.5534 * * *$ & $0.2798^{* *}$ & $0.1465^{* *}$ \\
\hline$(0.2613)$ & $(0.2110)$ & $(0.1424)$ & $(0.0612)$ \\
\hline $0.5942 * * *$ & $0.5528 * * *$ & 0.1254 & $0.1616^{* * *}$ \\
\hline$(0.2184)$ & $(0.1764)$ & $(0.1191)$ & $(0.0511)$ \\
\hline 0.0925 & 0.0513 & 0.0574 & 0.0176 \\
\hline (0.1099) & $(0.0887)$ & $(0.0599)$ & $(0.0257)$ \\
\hline $0.4331 * * *$ & $0.4220^{* * *}$ & 0.0657 & $0.1317 * * *$ \\
\hline$(0.1545)$ & $(0.1248)$ & $(0.0842)$ & $(0.0362)$ \\
\hline-0.0708 & -0.0622 & -0.0136 & -0.0143 \\
\hline$(0.0689)$ & $(0.0556)$ & $(0.0375)$ & $(0.0161)$ \\
\hline $\begin{array}{l}0.1892 * * * \\
(0.0457)\end{array}$ & $\begin{array}{l}0.1268^{* * *} \\
(0.0369)\end{array}$ & $\begin{array}{l}0.0791 * * * \\
(0.0249)\end{array}$ & $\begin{array}{l}0.0330 * * * \\
(0.0107)\end{array}$ \\
\hline & & & - \\
\hline$-0.1378^{* * *}$ & $-0.1076^{* * *}$ & $-0.0488^{*}$ & $0.0332^{* * *}$ \\
\hline$(0.0475)$ & $(0.0384)$ & $(0.0259)$ & $(0.0111)$ \\
\hline$-0.1337 * *$ & $-0.1009 * *$ & -0.0554 & $-0.0334 * *$ \\
\hline$(0.0632)$ & $(0.0510)$ & $(0.0345)$ & $(0.0148)$ \\
\hline & - & 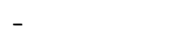 & 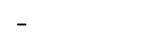 \\
\hline$-36.6010^{* * *}$ & $25.5756^{* * *}$ & $15.9354^{* * *}$ & $7.1823^{* * *}$ \\
\hline$(8.0013)$ & $(6.4606)$ & $(4.3612)$ & $(1.8727)$ \\
\hline 1921 & 1921 & 1921 & 1921 \\
\hline
\end{tabular}

DEMOGRAPHIC AND EDUCATION

African American (0/1)

Some college $(0 / 1)$

Graduate school (0/1)

Intercept

\begin{tabular}{ll} 
& $(0.0632)$ \\
& $-36.6010 *$ \\
& $(8.0013)$ \\
\hline
\end{tabular}

Numbers in the parentheses are the standard deviations.

$*, * *$ and ${ }^{* * *}$ statistical significance at the $10 \%, 5 \%$, and $1 \%$ levels. 
Table 4. Mortgage Foreclosure, 2009-2011

\begin{tabular}{|c|c|}
\hline Interviewed after August 2009 & $\begin{array}{l}0.0216 \\
(0.0250)\end{array}$ \\
\hline MORTGAGE AND HOME FINANCIAL MEASURES & \\
\hline Whether original mortgage $(0 / 1)$ & $\begin{array}{l}-0.0112 \\
(0.0097)\end{array}$ \\
\hline Year of original mortgage & $\begin{array}{l}0.0022 * \\
(0.0012)\end{array}$ \\
\hline Case-Shiller index decline $(07-09)>=15 \%$ but $<35 \%$ & $\begin{array}{l}0.0072 \\
(0.0205)\end{array}$ \\
\hline Case-Shiller index decline (07-09) $>=35$ & $\begin{array}{l}0.0614^{* * *} \\
(0.0220)\end{array}$ \\
\hline Housing payment ratio & $\begin{array}{l}0.1655^{* * *} \\
(0.0452)\end{array}$ \\
\hline INCOME AND BALANCE SHEET & \\
\hline Income head 2007 (M) & $\begin{array}{l}0.2986 * * \\
(0.1454)\end{array}$ \\
\hline Income head $2008(\mathrm{M})$ & $\begin{array}{l}-0.2786^{*} \\
(0.1435)\end{array}$ \\
\hline Income wife 2007 (M) & $\begin{array}{l}0.3714 \\
(0.3444)\end{array}$ \\
\hline Income wife $2008(\mathrm{M})$ & $\begin{array}{l}-0.4947 \\
(0.3105)\end{array}$ \\
\hline Number of people in household & $\begin{array}{l}0.0027 \\
(0.0041)\end{array}$ \\
\hline wealth without equity $2007<0$ & $\begin{array}{l}0.0676^{* * *} \\
(0.0171)\end{array}$ \\
\hline $0<$ wealth without equity $2007<=5,000$ & $\begin{array}{l}0.0185 \\
(0.0219)\end{array}$ \\
\hline $5,000<$ wealth without equity $2007<=10,000$ & $\begin{array}{l}-0.0420 * * \\
(0.0209)\end{array}$ \\
\hline $50,000<$ wealth without equity $2007<=79,000$ & $\begin{array}{l}-0.0341 * * \\
(0.0172)\end{array}$ \\
\hline wealth without equity $2007>79,000$ & $\begin{array}{l}-0.0119 \\
(0.0127)\end{array}$ \\
\hline value of checking and saving $2007<=2000$ & $\begin{array}{l}0.0007 \\
(0.0119)\end{array}$ \\
\hline LABOR MARKET STATUS & \\
\hline Laid off head 2007 & $\begin{array}{l}0.1112 \\
(0.0791)\end{array}$ \\
\hline Unemployed head 2007 & $\begin{array}{l}0.0986^{* * *} \\
(0.0350)\end{array}$ \\
\hline Retired head 2007 & $\begin{array}{l}0.0135 \\
(0.0320)\end{array}$ \\
\hline Disabled head 2007 & $\begin{array}{l}0.1158^{* *} \\
(0.0514)\end{array}$ \\
\hline Keeping house head 2007 & $\begin{array}{c}-0.1119 \\
(0.0852)\end{array}$ \\
\hline
\end{tabular}


No wife $2007 \quad-0.0155$

Laid off wife 2007

0.0222

$(0.0534)$

Unemployed wife 2007

$-0.0221$

$(0.0483)$

Retired wife 2007

$-0.0494$

$(0.0367)$

Disabled wife 2007

$-0.0765^{*}$

$(0.0433)$

Keeping house wife 2007

$-0.0399 * *$

$(0.0192)$

Laid off head 2009

0.0070

$(0.0560)$

$0.0424 *$

$(0.0224)$

$0.0937^{* *}$

(0.0463)

$0.1348^{*}$

(0.0771)

$0.0012^{* *}$

(0.0006)

$0.1636 * *$

(0.0643)

0.0292

$(0.0329)$

0.0406

$(0.0457)$

$-0.0083$

$(0.0210)$

$-0.0008^{*}$

Work weeks wife 2008

$(0.0005)$

DEMOGRAPHIC AND EDUCATION

African American (0/1) 0.0246*

$(0.0137)$

$-0.0147$

Some college $(0 / 1)$

$(0.0144)$

Graduate school (0/1)

$-0.0165$

$(0.0191)$

$-4.4556^{*}$

Intercept

$(2.4600)$

\begin{tabular}{ll}
\hline Number of observations & 1827 \\
\hline
\end{tabular}

Note:

Included variables but not reported are: age categories, city size, region, and some labor market status measures such as student and retired which bore no relationship to the outcome. Available upon request.

Numbers in the parentheses are the standard deviations.

$*, * *$ and $* * *$ statistical significance at the $10 \%, 5 \%$, and $1 \%$ levels. 
Figure 1. Percent of Home-owning Families Holding a Mortgage

(Age 25-34, 35-49, 50-64 and 65 and older)

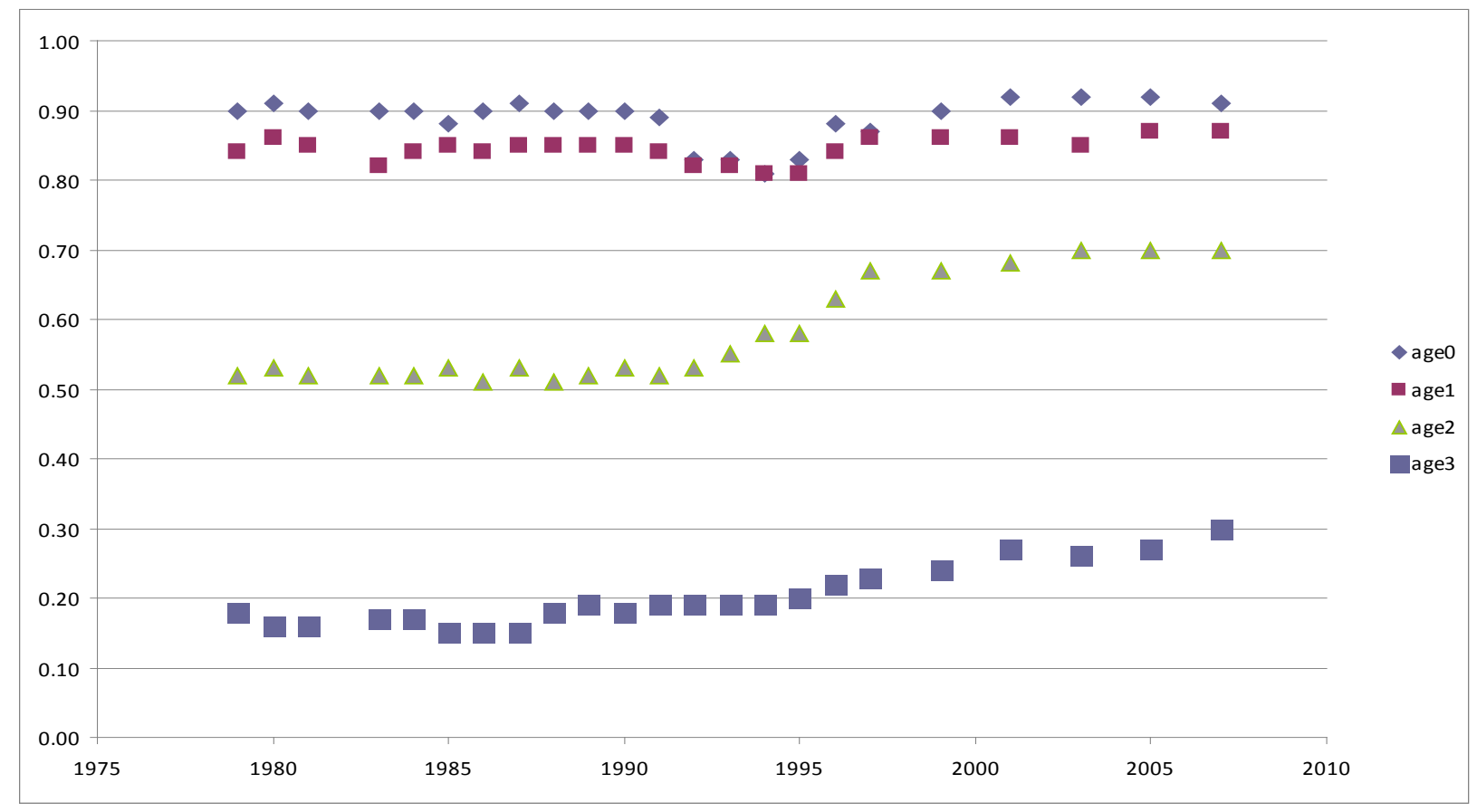


Figure 2. Adjustable Rate Mortgage as the Primary Loan by Year of Origin

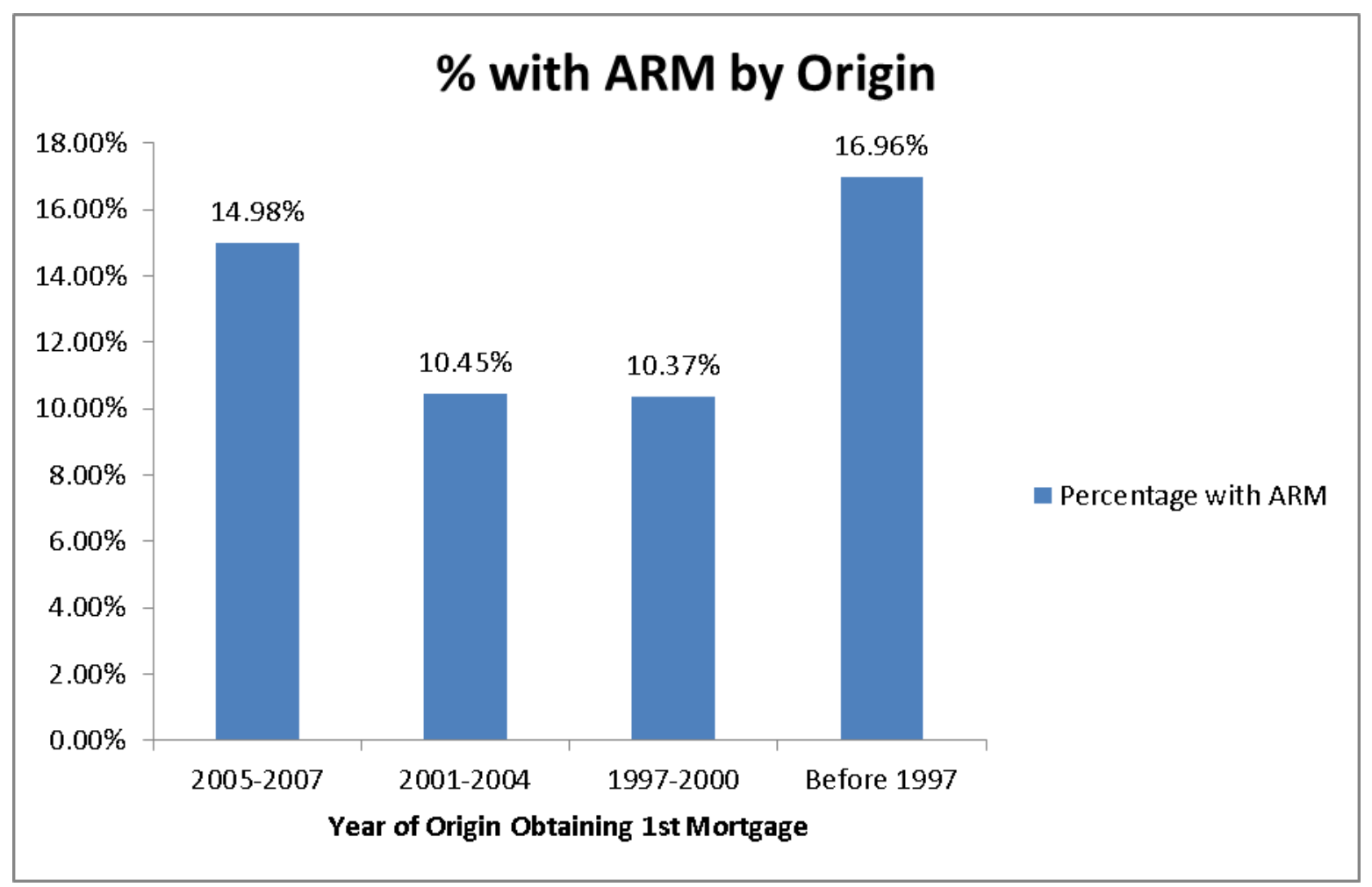

